\title{
A structured approach to the concept of a (safe) system of work
}

\section{CRAIG BRAUN, SIOBHAN BROPHY, MOHAMED JASSIM, ELAINE MILLS, PARUL DAGAR, CHRISTOPHER PEACE*, ALLISTER ROSE and MIA WICHMAN}

\begin{abstract}
The concept of a "safe system of work" (SSW), sometimes known as a "system of work that is safe", is often a required risk control in countries that follow English common law or that have Robens-style legislation, but it sits low in the hierarchy of controls. A request for advice on what constitutes a safe system of work led to a literature search that found no commonly accepted description or generic model for a safe system of work.
\end{abstract}

A literature search for SSW was carried out, including the origins of the concept and its use in statute and common law in the UK and New Zealand (NZ). Findings suggested a systems management approach to develop a tentative goal tree (part of the Theory of Constraints) to structure the themes. The goal tree was tested iteratively using a set of small-scale case studies.

The literature and research showed that a safe system should control how an individual work activity is carried out as it forms part of a larger health and safety management system. The tentative goal tree was found to provide a framework within which the case studies could be analysed and compared. It appeared to be applicable to other cases in a range of workplaces and to enable testing of a planned or existing system of work to help decide if a proposed system of work was "safe".

The literature review provided background to the concept of a safe system of work and enabled development of a tentative goal tree to help plan or test a safe system of work.

Keywords: duty of care; goal tree; law; Robens; safety management system; negligence; safe system of work

\section{Introduction}

In 2019, a prosecution involving harm to workers led to a request to Christopher Pearce for advice about the meaning of a "safe system of work" (SSW) required under NZ legislation. A brief literature search found no common definition of the term or investigation of what might constitute a generic

\footnotetext{
* Contact author: Christopher Peace christopher.peace@ vuw.ac.nz

Lecturer in OHS, School of Health, Victoria University of Wellington, New Zealand

Co-authors: Victoria University of Wellington, New Zealand

\section{Acknowledgements, funding and authorship}

The comments of an anonymous reviewer are acknowledged.

This research did not receive any funding from public, commercial, or not-for-profit entities.

$\mathrm{CP}$ researched the literature and drafted the paper. The co-authors contributed the contents of tables 2 and 3 and discussion during a workshop.
} 
SSW, confirming that "what constitutes, or should have constituted, a safe system of work is often clearer with hindsight" (Borys et al., 2012, p. 6), and making difficult the recognition of a system of work that is "safe".

At a time when the boundaries of occupational health and safety (OHS) are expanding to include mental health, it is not satisfactory for stakeholders to have no clear idea what may constitute a SSW. This led to the pragmatic research question: what constitutes a safe system of work under the requirements of Robens-style legislation?

\section{Methodology}

To respond to the research question, we reviewed the meaning of SSW under UK common law up to 1975 (nearly half a century ago) and how it informed the development of UK statute law. We outlined the requirements of some UK and NZ legislation for "systems of work" that are "safe", and explored concepts about systems management, standard sources, and some recent prosecutions. Subsequently, we examined a sample of cases under the New Zealand Health and Safety at Work Act (keywords "system of work") downloaded from the website of the Chief Judge of the District Court. The data from these sources was analysed thematically and is presented graphically in a tentative goal tree (Dettmer, 2007; 2011) for an effective SSW. This was then used to help analyse a set of case studies where no harm had been reported, and to help determine its effectiveness as a planning and testing tool.

\section{The UK common law up to 1975}

Munkman (1975) showed the concept of a SSW had evolved in UK common law over a 140-year period, resulting in a body of case law that contributed to the development of the UK Health and Safety at Work Act (1974) and, indirectly, the NZ Health and Safety at Work Act (2015). Munkman's review of some of the cases suggested the term SSW is used flexibly in relation to the specifics of each case.

Munkman (1975), writing about the need for a SSW as part of the duty of care owed by employers to their employees, argued that the employer

is responsible for the general organisation of the [workplace] ... This organisation or 'system' $\ldots$ is required - independently of safety - for the purpose of ensuring that the work is carried out smoothly and competently ... Accordingly, the employer's personal liability for an unsafe system ... is not founded on an artificial concept, but is directly related to the facts of industrial organisation (pp.131-132).

This can be interpreted as a description of a management system that includes a SSW where the absence of a SSW might be identified as negligent behaviour.

Negligence in common law was described by Alderson $\mathbf{J}$ as "the omission to do something which a reasonable man, guided upon those considerations which ordinarily regulate the conduct of human affairs, would do: or doing something which a prudent and reasonable man would not do" (Blyth v Birmingham Waterworks, 1856). As noted below, in 1974, the common law duty of care became a cornerstone of the UK Health and Safety at Work Act. The absence of, or a deficient, SSW has often been cited in common law litigation in the UK and Australia as a breach of the duty of care owed by an employer to employees. In a leading UK case (Wilsons \& Clyde Coal Co Ltd v English, 1937), Wright LJ stated the duty of an employer includes a SSW. 
Munkman (1975) suggested that there were five common situations when a SSW should be provided. These, and some examples of "defective systems" that resulted in litigation, are summarised in Table 1.

Table 1. When a SSW might be required

\begin{tabular}{|c|c|c|}
\hline $\begin{array}{l}\text { Munkman's } \\
\text { description }\end{array}$ & Examples & $\begin{array}{c}\text { Examples of "defective systems" from } \\
\text { Munkman pp. 138-144 }\end{array}$ \\
\hline $\begin{array}{l}\text { Settled or permanent } \\
\text { nature of work }\end{array}$ & $\begin{array}{l}\text { Permanent organisation with } \\
\text { similar repeated operations, } \\
\text { perhaps evidenced by a standard } \\
\text { method }\end{array}$ & \multirow{5}{*}{$\begin{array}{l}\text { Faulty: } \\
\text { - } \text { coordination of departments where } \\
\text { - } \text { one may endanger the other } \\
\text { - } \text { method of using particular machines } \\
\text { processes (eg, cleaning a machine in } \\
\text { motion) } \\
\text { - planning for a specific task, } \\
\text { especially layout of the workplace } \\
\text { ("setting of the stage") } \\
\text { Failure to provide necessary: } \\
\text { - personal protective equipment, } \\
\text { including protective skin cream } \\
\text { - numbers of workers } \\
\text { - protection from attack by criminals } \\
\text { - } \text { system for handling heavy loads } \\
\text { - instructions, information, training or } \\
\text { - } \text { supervision } \\
\text { - information about the limits of plant } \\
\text { - interlocks on machine guards } \\
\text { - testing of the atmosphere in a } \\
\text { - confined space before entry } \\
\text { - } \text { access to the workplace } \\
\text { - } \text { exposed to tuberculosis } \\
\text { substitute for substances that may } \\
\text { prentilation, lighting or fire } \\
\text { precautions }\end{array}$} \\
\hline $\begin{array}{l}\text { Varies from time to } \\
\text { time }\end{array}$ & $\begin{array}{l}\text { A proper system for each new task } \\
\text { might be required }\end{array}$ & \\
\hline $\begin{array}{l}\text { Isolated tasks } \\
\text { requiring } \\
\text { organisation }\end{array}$ & $\begin{array}{l}\text { Such tasks might be organised } \\
\text { through a permit-to-work system } \\
\text { because it is complicated or } \\
\text { unusual (eg, maintenance } \\
\text { activities) }\end{array}$ & \\
\hline $\begin{array}{l}\text { Allowance for } \\
\text { infirmities or } \\
\text { inexperience }\end{array}$ & $\begin{array}{l}\text { The classical example given by } \\
\text { Munkman (1975) is provision of } \\
\text { eye protection when a worker has } \\
\text { already lost the sight in one eye }\end{array}$ & \\
\hline $\begin{array}{l}\text { Duty to establish and } \\
\text { enforce a system: } \\
\text { "casual departure" }\end{array}$ & $\begin{array}{l}\text { An employer who has established } \\
\text { a written SSW but not put it into } \\
\text { regular operation or who has } \\
\text { allowed it to lapse might be in } \\
\text { breach of their duty of care. There } \\
\text { is a clear breach of the duty if a } \\
\text { dangerous system has been taught } \\
\text { by or on behalf of the employer }\end{array}$ & \\
\hline
\end{tabular}




\section{UK legislation}

The UK Robens Report recommended new legislation that would draw on the common law duty of care, including for "safe working systems" (Lord Robens et al., 1972, p. 51) and apply to all workers and workplaces. The Act became law in the UK in 1974 with section 2(2) requiring "the provision and maintenance of ... systems of work that are, so far as is reasonably practicable, safe and without risks to health".

Two cases under the UK Act illustrate some components of a SSW that might now be expected by the courts and show similarities to "defective systems" listed in Table 1. The first case (IOSH, 2018) found that no pre-employment checks forming part of a SSW had been carried out by a golf club prior to employment of a worker who had not been trained to use a chainsaw and who was working alone at night when he was killed by a falling tree branch. In an earlier UK case, IOSH (2016) reported "a completely unsafe system of work" involving maintenance work outside a crane cab some 40 metres above the ground in a coal-handling plant. There was no safe access to the workplace (the roof of the crane cab) and no means of warning of or escape from imminent danger.

\section{NZ legislation}

New Zealand introduced the "no fault" accident compensation scheme (Woodhouse et al., 1967) and of a statutory bar on claims for negligence under the common law in the 1970s. This meant employers had fewer incentives to develop and maintain occupational health and safety-related management systems generally (Campbell, 1996; Peace, 2008) and SSW, specifically. However, the quality of the legislation and its enforcement remained poor, and employers had no incentive to provide or maintain a SSW (Peace et al., 2019).

After the 2010 Pike River mine disaster, new legislation, based on Australia's Model Work Health and Safety Bill (2011), which was substantially derived from the UK Health and Safety at Work Act (1974), was recommended (Jager et al., 2013).

The NZ Health and Safety at Work Act 2015 (HSWA) uses the term "person conducting a business or undertaking" (abbreviated in the Act to PCBU) instead of "employer". Section 36(3) requires that "a PCBU must ensure so far as is reasonably practicable ... (c) the provision and maintenance of safe systems of work". The Act does not provide a concise description or definition of a safe and healthy system of work, a potentially significant omission.

\section{Cases in the NZ District Court 2016-2020}

A brief search of cases decided in the District Court from 2016 (when the HSWA came into force) to 2020 for "safe system of work" found the following cases that included some mention of a SSW. Other cases may also mention SSW; the full data set requires a more detailed analysis in further research. The following cases under the NZ Act illustrate similarities with "defective systems" in Table 1.

The need to take account of operating limits of "plant" (including, in NZ, a vessel) was noted by Justice Davidson in a Maritime NZ prosecution (the origin of the enquiry that led to this article) for gross overloading of a fishing trawler causing the vessel to sink (Maritime New Zealand $v$ Nino's Ltd, Antonio Innocenzo Basile, Shane Michael McCauley, 2020). 
In a case heard by Justice Mill (WorkSafe NZ v Enviro Waste Services Ltd, 2016), a waste collection company was convicted for the death of a worker following failure to train the worker in the correct operation of a bin-lifting machine attached to a truck.

A "failure to develop, document, implement and communicate an adequate safe system of work for the unloading of wagons" resulted in the death of a worker while unloading rail wagons (Worksafe NZ $v$ Toll Networks NZ Ltd, 2018). The SSW should have led to the control of the operation of a forklift truck near a pedestrian worker.

Failure "to develop and implement a safe system of work and ensure that the machine was adequately guarded" resulted in harm to a worker's hand (Worksafe NZv Furntech Plastics Ltd, 2018). A SSW should have ensured that the (plastic moulding) machine was correctly isolated before going ahead to change a mould.

An unguarded prototype machine and the absence of an adequate SSW for "testing and modification" of the machine led to serious harm of a worker's hand (Worksafe NZ v Lets Bale Ltd, 2020).

In WorkSafe NZ v Precision Animal Supplements Limited, 2018), a case involving exposure to dust (Justice Roberts decided:

It was reasonably practicable for the company to have:

a) Developed, documented, implemented and communicated an adequate safe system of work.

b) Provide and maintain a safe work environment that minimised the exposure of the workers to substances hazardous to health.

c) Adequately monitored the ongoing health of workers to identify any changes in their health status due to exposure to substances hazardous to health.

This description identified many features that a SSW should address

\section{Literature review}

The literature review used the keyword search "safe system of work" or "system of work" and occupation, yielding 4,965 results. A further search within these results found 98 that included safe system of work. However, 29 were reports of prosecutions published in the UK Safety and Health Practitioner 1998-2015 and a further six were reports of prosecutions and common law claims in other sources.

Some articles presented a narrow occupational view (e.g., in relation to mental health, surgery or the police) or exhorted development of a SSW without suggesting what a generic SSW should include. A separate search within the journal Safety Science found 165 articles that mentioned SSW but did not suggest what a generic SSW might contain. These results again confirmed that "what constitutes, or should have constituted, a safe system of work is often clearer with hindsight" (Borys et al., 2012, p. $6)$. 


\section{OHS sources}

Stranks (2010)) thought a SSW should include a "correct sequence of operations, safe working area layout, and controlled environment ..." (pp.102-103), and that a SSW should be designed after carrying out a job safety analysis.

The OSH Branch (2004) of the Hong Kong Labour Department published guidance for the development of a SSW including the following five steps:

- assess the task

- identify the hazardss

- define safe methods

- implement the system

- monitor the system.

Chan et al., (2008), summarising 22 construction sector fatalities in Hong Kong, showed that in 11 the "top recommendation was "provide and maintain a safe system of work" but gave no definition or detail of a SSW. Holt (2005) thought that a SSW "identifies safe methods of work to ensure that the hazards are eliminated or the remaining risks are minimised" (pp.24-25). All SSW should be subject to effective supervision and monitoring to detect changes in context or differences between "work as imagined" and "work as done" (Dekker, 2014).

Michie (2002) extended traditional OHS to include stress, arguing that "creating a SSW requires targeting equipment, materials, the environment and people (for example, ensuring sufficient skills for the tasks)". These also require monitoring and review to ensure they remain effective.

\section{Standards and similar sources}

A SSW may form part of an overall OHS management system. Accordingly, two relevant management systems were used to search for a definition and/or description of a SSW. A system called SafePlus (https://www.worksafe.govt.nz/managing-health-and-safety/businesses/safeplus/) was developed by NZ Government agencies as a way of encouraging improvement of OHS in workplaces. Although the performance requirements (WorkSafe NZ, 2017) mention 'system' on five of the 33 pages, none relates specifically to a SSW. Similarly, the word 'system' was found on 46 of the 52 pages in the international standard ISO45001 (ISO, 2018) "Occupational health and safety management systems", but none specifically related to a SSW.

\section{Management sources}

Dyck (2003 pp.652-653) defined a system of work as "an interconnected set of highly specific work practices that help workers get the job done and enable organizations to fulfil their mission". A change in one part of a system would affect all other parts of the system, as suggested graphically in the McKinsey 7-S model (Waterman et al., 1980). Figure 1, shown below, include additions by Peace (2019, p. 120 \& 152); , and the "spider's web of interactions" (Makin \& Winder, 2009, p. 330) reproduced here as Figure 2. 
Figure 1. Mckinsey 7-s model with additions

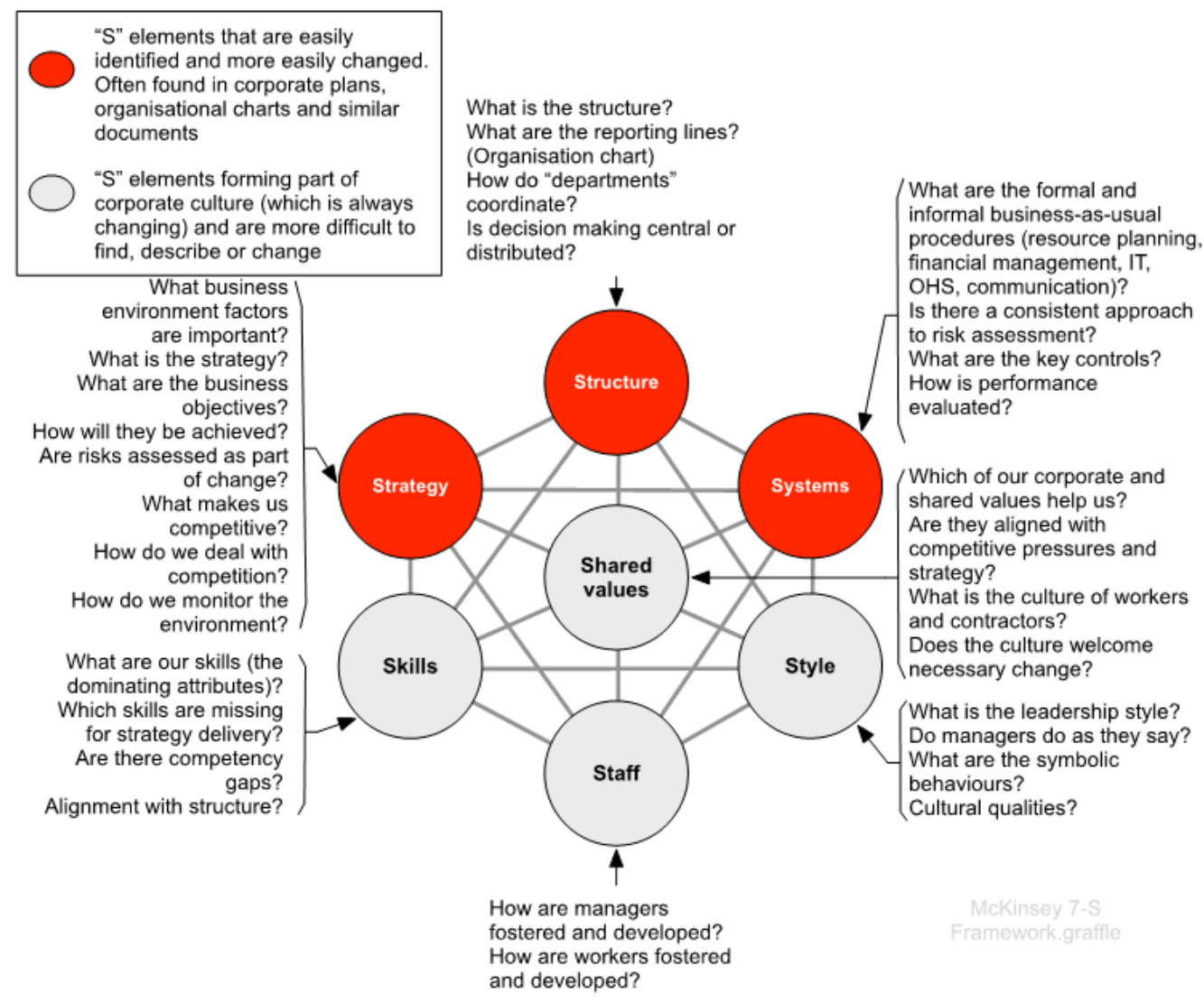

Sources: Waterman, Peters, \& Phillips (1980); Peters \& Waterman (1982) with additions by Peace (2020)

The 7-S model was used here as a diagnostic tool, showing that systems (e.g., of work) influence and are influenced by the other six elements. For example, asking what formal and informal business-asusual procedures exist may reveal systems of work that have gone unnoticed by others in an organisation. Such questions may show, for example, the need to make changes if a system of work is to become a SSW.

However, when used to aid analysis of whether operation of a fishing trawler, in the case giving rise to this research, the 7-S model did not obviously suggest consideration of the load limit of plant or equipment

The "spider's web of interactions" (Makin \& Winder, 2009, p. 330) posits nodes that might influence work processes and work practices and will, in turn, be influenced by those nodes. 
Figure 2. Impacts at work - a spider's web of interactions

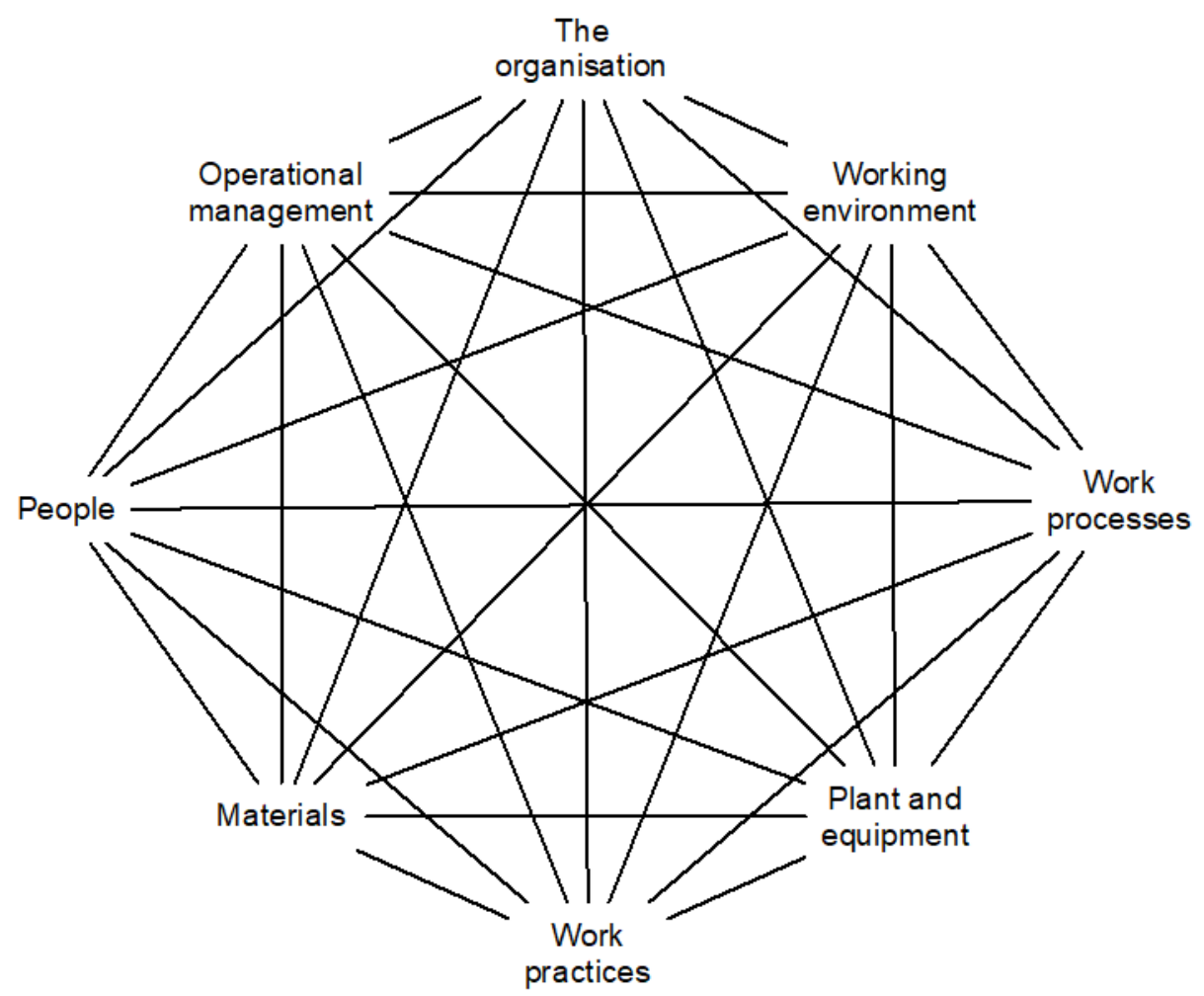

Source: Figure 1 Makin \& Winder (2009) Impacts at work - a spider's web of interactions

The quotation from Munkman (1975, pp. 131-132) cited earlier aligns with both models, confirming that a system can be seen as a "set of interrelated and interdependent parts arranged in a manner that produces a unified whole" (Robbins et al., 2003, pp. 16) and that contains "hard system" and "soft system" elements (Waring, 1996, p. 224 \& 227).

However, the Makin \& Winder model does not obviously suggest a system that will aid diagnosis of occupational mental illness (Poole, 2008). Nor would the model or the 7-S model suggest investigation of exposures to substances such as "surgical smoke" (Addley \& Quinn, 2019), emitted by the use of new technologies in surgical operations, potentially giving rise to occupational ill health. Such surgical operations can be prone to errors due to distractions (Healey et al., 2007), requiring monitoring of errors as indicators of fatigue (Dawson et al., 2012).

\section{Thematic analysis of literature and case studies}

A thematic analysis of the literature discussed above showed a SSW should be preceded by a risk assessment using relevant techniques (e.g., job safety analysis, task analysis) that has been carried out jointly with the workers who are to carry out the task. This might identify:

- any information, training, or instruction required for workers to be considered to be competent

- the number of competent workers needed to carry out the work under normal and emergency situations 
- identification of supervision and monitoring arrangements under normal and emergency situations.

- the activity to be carried out (whether permanent, variable between workplaces, plant, shifts, time of day or people, or one-off/isolated)

- normal, emergency and maintenance procedures required

- substances to be used, and normal, emergency and maintenance procedures for their use

- any plant to be used and relevant normal, emergency and maintenance procedures for operation of the plant

- the workplace and environment where work is carried out normally or in an emergency

- previously unidentified issues.

A SSW might be verbal for simple or low-risk activities, but for more complex or higher risk activities it should be written, describing the system of work in plain English or using graphics (Praino \& Sharit, 2016), and supported by effective training.

Even a highly effective SSW may drift from the intended system and become less effective. Thus, the higher the level of risk that a SSW should fail, the more frequently the system should be subject to management review and internal audit as part of a wider safety management system.

The above list might be used as a checklist but could become a "work-system induced risk" due to "involuntary automaticity" - skilled repeating of a task, believing it to be safe when a key step is incomplete or has been missed (Toft \& Mascie-Taylor, 2005). Conversely, a goal tree (Dettmer, 2007; 2011) can set out the same information but, in a tree layout, containing critical success factors (CSF) and necessary conditions (NC) if the goal of (in this instance) a SSW is to be achieved. Each CSF must be achieved and the NC are those enabling the successes. A goal tree might provide a frame that aids learning and adaptation, helping to provide "latent scripts for response to future possibilities that would require rapid and practiced coordination" (Rochlin, 1999, pp. 1552-1553).

\section{A structured approach: a tentative goal tree for a SSW}

Figure 3 is a tentative goal tree for a SSW, derived from the literature review and based on the above list. It was used to examine the systems of work in the case studies and examples described below. 
Figure 3. Tentative goal tree for a generic safe system of work

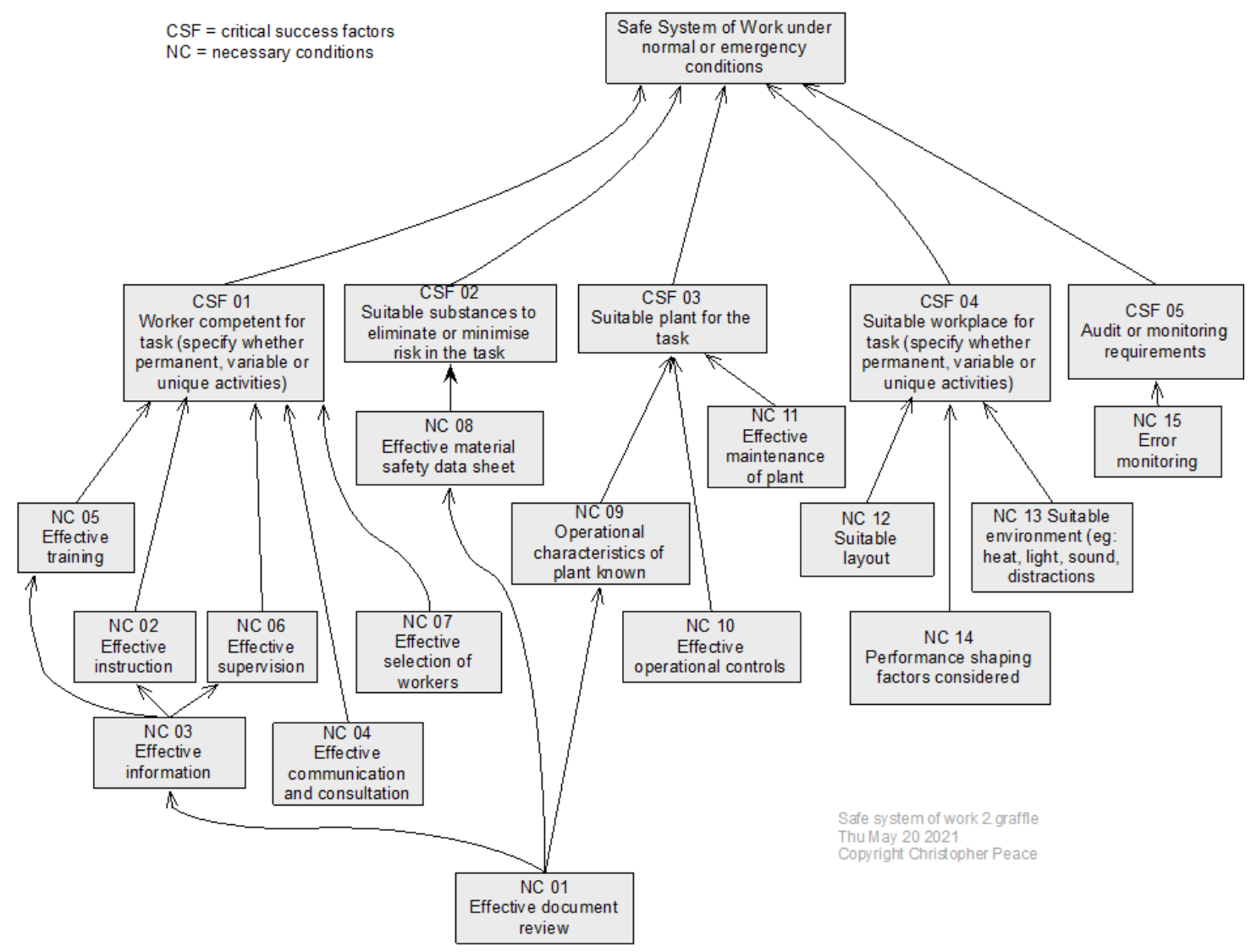

This goal tree contains five critical success factors (CSF) and 15 necessary conditions (NC). Using necessity logic, in order to achieve the goal of a SSW and, working from the bottom up, each NC must be achieved or identified as not relevant before the relevant CSF can be shown to be achieved (Dettmer, 2007; 2011). When each CSF has been achieved, the goal of a SSW under normal or emergency conditions is likely to be achieved. Thus, if a CSF is to be achieved, deficiencies in knowledge about the worker, any substances in use or produced by the process, the plant, and the workplace will have been identified and remedied, and an effective audit or monitoring system put in place.

\section{Small-scale case studies}

Table 2 summarises a set of small-scale case studies and Table 3 uses information from each case to show if NCs and the related CSFs were achieved. 
Table 2. Summary of case studies

\begin{tabular}{|c|c|}
\hline $\begin{array}{l}\text { Case study } \\
\text { identifier }\end{array}$ & Brief background information \\
\hline $\mathbf{A}$ & $\begin{array}{l}\text { In November 2019, due to a refurbishment project timed for 2020/2021, Case A moved } \\
\text { two technology workshops from a building erected in the 1960s to temporary } \\
\text { accommodation on a mezzanine floor and concrete ground floor. } \\
\text { The current system of work for lathes and pedestal drills was particularly geared for the } \\
\text { induction of higher numbers of new workers at the beginning of each year. There is a } \\
\text { greater chance that a new worker starting part way through the year may miss out on } \\
\text { training or supervision due to the workshop being in full operation. A professional } \\
\text { development project was planned to address this control deficiency. }\end{array}$ \\
\hline B & $\begin{array}{l}\text { The company grew and supplied raw materials to domestic and foreign markets. The } \\
\text { office workers used an espresso machine posing risks from hot surfaces, hazardous } \\
\text { substances and inadequate hygiene. } \\
\text { The operating and cleaning manuals did not include the entire system and did not, for } \\
\text { example, explain how to clean the milk jugs. Nor were they known about or followed } \\
\text { by those in the organisation. The espresso machine was the type used in a commercial } \\
\text { setting and not appropriate for an office environment. }\end{array}$ \\
\hline $\mathbf{C}$ & $\begin{array}{l}\text { The system of work was for deglazing a cracked vehicle windscreen using a cutting } \\
\text { wire method and then fitting a new windscreen. The task posed risks from sharp edges, } \\
\text { manual handling, falls from a height, slips and trips, exposure to chemicals, and } \\
\text { collisions between vehicles and vehicles and pedestrians. Exposure to chemicals and } \\
\text { collisions were not covered by the task analysis and, therefore, less than adequate. }\end{array}$ \\
\hline D & $\begin{array}{l}\text { The safe system of work was for the operation of a recently imported, second-hand } \\
\text { four-colour offset printing press of a common design that posed risks due to unguarded } \\
\text { moving parts. Avoidance of harm appeared to rely on the common sense approach of } \\
\text { not putting a hand into the moving parts. Anecdotal evidence suggested the machines } \\
\text { are common both locally and internationally and that few in NZ were fitted with guards } \\
\text { on the paper-feed opening. }\end{array}$ \\
\hline $\mathbf{E}$ & $\begin{array}{l}\text { Case study E was a small heat pump installation and servicing company. While the } \\
\text { focus of the case study was electrical safety, there were other hazards, including dust, } \\
\text { hazardous substances and adverse weather. The planned system had been adapted by } \\
\text { one worker to include the use of an electrical test meter and the use of a cable tie to } \\
\text { show that a machine had been de-energised. }\end{array}$ \\
\hline $\mathbf{F}$ & $\begin{array}{l}\text { Case study F provides and handles IT resources, expertise, support and services for } \\
\text { large organisations nationwide. The case study focused on the system of handling } \\
\text { extension cords and power strips in the test room, which was originally for storage and } \\
\text { packaging, but has been repurposed for testing laptops and computer systems. } \\
\text { Overloading of extension cords and power strips can cause fires, and wear and tear of } \\
\text { insulation can expose live conductors and the cables can be trip hazards. }\end{array}$ \\
\hline $\mathbf{G}$ & $\begin{array}{l}\text { Case Study } \mathrm{G} \text { examined the system of work while a barista used an espresso machine } \\
\text { to brew coffee in a busy cafe. This activity has multiple OHS risks, including } \\
\text { burns/scalds, and spills, slips/trips/falls causing musculoskeletal injury. }\end{array}$ \\
\hline
\end{tabular}


Table 3. Analysis of CSF and NC in the case studies

(Notes to table: $\mathrm{LTA}=$ less than adequate or absent; PPE = personal protective equipment)

\begin{tabular}{|c|c|c|c|c|}
\hline & \multicolumn{4}{|c|}{ Critical success factors and necessary conditions } \\
\hline $\begin{array}{l}\text { Case } \\
\text { identifier }\end{array}$ & CSF 01 & CSF 02 & CSF 03 & CSF 04 \\
\hline $\mathrm{A}$ & $\begin{array}{l}\text { NC 01: electronic database } \\
\text { enables document review } \\
\text { NC 03: effective } \\
\text { information } \\
\text { NC 05: four-week } \\
\text { induction training course } \\
\text { NC 06: reviews by } \\
\text { supervisor and safety } \\
\text { representative }\end{array}$ & $\begin{array}{l}\text { Not applicable in this } \\
\text { case }\end{array}$ & $\begin{array}{l}\text { NC 10: machines } \\
\text { guarded, chuck keys } \\
\text { secured to drills } \\
\text { NC 10: PPE provided } \\
\text { NC 11: planned } \\
\text { maintenance }\end{array}$ & $\begin{array}{l}\text { NC 12: provision of } \\
\text { pedestrian walkways } \\
\text { NC 13: separation of hot } \\
\text { work from dusty work, and } \\
\text { provision of local extract } \\
\text { ventilation }\end{array}$ \\
\hline B & $\begin{array}{l}\text { NC 01: incomplete } \\
\text { document review } \\
\text { NC 05: training of users } \\
\text { was LTA }\end{array}$ & $\begin{array}{l}\text { NC 08: coffee bean } \\
\text { dust control was } \\
\text { LTA } \\
\text { NC 08: storage of } \\
\text { cleaning materials } \\
\text { was LTA }\end{array}$ & $\begin{array}{l}\mathrm{NC} 10: \text { operational } \\
\text { controls to prevent } \\
\text { scalds were LTA }\end{array}$ & $\begin{array}{l}\text { NC 12: suitable workplace } \\
\text { layout }\end{array}$ \\
\hline $\mathrm{C}$ & $\begin{array}{l}\text { NC 01: task analysis LTA } \\
\text { NC 05: workers trained in } \\
\text { manual handling and work } \\
\text { at heights }\end{array}$ & $\begin{array}{l}\text { NC 08: data sheets } \\
\text { not provided }\end{array}$ & NC 10: PPE provided & $\begin{array}{l}\mathrm{NC} \quad 12: \quad \text { effective } \\
\text { housekeeping and access to } \\
\text { work but consideration of } \\
\text { vehicle movements LTA }\end{array}$ \\
\hline $\mathrm{D}$ & $\begin{array}{l}\text { NC: } 01 \text { incomplete } \\
\text { document review } \\
\text { NC 02: manual not in } \\
\text { English } \\
\text { NC 05: no bespoke training }\end{array}$ & $\begin{array}{l}\text { Not applicable in this } \\
\text { case }\end{array}$ & $\begin{array}{l}\text { NC 09: incomplete } \\
\text { knowledge } \\
\text { operational } \\
\text { characteristics } \\
\text { NC 10: machine guard } \\
\text { missing }\end{array}$ & No applicable in this case \\
\hline $\mathrm{E}$ & $\begin{array}{l}\text { NC 01: the document } \\
\text { review appeared to be LTA } \\
\text { NC 02: instruction was a } \\
\text { verbal "run through", thus } \\
\text { also LTA } \\
\text { NC 05: there was no formal } \\
\text { training in heat pump } \\
\text { servicing, including use of } \\
\text { cleaning substances }\end{array}$ & $\begin{array}{l}\text { NC 08: small, } \\
\text { operational } \\
\text { quantities of the } \\
\text { cleaning substances } \\
\text { were not labelled } \\
\text { NC 08: the material } \\
\text { data sheet made } \\
\text { requirements for the } \\
\text { use of PPE but this } \\
\text { had not been } \\
\text { provided }\end{array}$ & $\begin{array}{l}\text { NC 09: it was unknown } \\
\text { if the operational } \\
\text { characteristics of each } \\
\text { type of heat pump had } \\
\text { been identified } \\
\text { NC 10: there was no } \\
\text { procedure to ensure the } \\
\text { correct pump in an array } \\
\text { of pumps had been de- } \\
\text { energised }\end{array}$ & $\begin{array}{l}\text { NC 12: heat pumps may } \\
\text { vary in layout and location } \\
\text { between sites and over time } \\
\text { NC 13: heat pumps may be } \\
\text { located in places exposed to } \\
\text { adverse weather }\end{array}$ \\
\hline $\mathrm{F}$ & $\begin{array}{l}\mathrm{NC} 01: \text { no document } \\
\text { review had been carried out } \\
\text { prior to repurposing the } \\
\text { room }\end{array}$ & $\begin{array}{l}\text { Not applicable in } \\
\text { this case }\end{array}$ & $\begin{array}{l}\text { NC 09: the total load on } \\
\text { the electrical circuit had } \\
\text { not been identified } \\
\text { NC 10: the necessary } \\
\text { permanently wired } \\
\text { sockets and overload } \\
\text { protection had not been } \\
\text { provided }\end{array}$ & $\begin{array}{l}\mathrm{NC} \text { 12: the layout of the } \\
\text { room was LTA }\end{array}$ \\
\hline G & $\begin{array}{l}\text { NC } 02 \text { and } 05 \text { : the barista } \\
\text { had been instructed and } \\
\text { trained in use of the } \\
\text { machine }\end{array}$ & Not recorded & $\begin{array}{l}\text { NC 10: an automatic } \\
\text { tamping machine } \\
\text { minimises repetitive } \\
\text { strain, cups are not held } \\
\text { while filling with hot } \\
\text { water }\end{array}$ & $\begin{array}{l}\text { NC 12: somewhat limited } \\
\text { workspace with other } \\
\text { workers walking behind; } \\
\text { liquid spills cannot be } \\
\text { cleaned up when very busy }\end{array}$ \\
\hline
\end{tabular}


Table 3 shows the lack of, or an ineffective document review, were a recurring weaknesses in four case studies, weakening other necessary conditions and, thus, achievement of the critical success factors and the goal of a SSW.

Although Case Study A had an effective SSW in place, a weakness in training was identified that was to be remedied later in the year. Case Study B was judged to be ineffective, needing to be improved by documentation and training.

The task analysis in Case Study $\mathrm{C}$ was less than adequate as it did not consider two exposures or impact by moving vehicles; as a result the SSW was not effective. Case study D found the root cause of the ineffective SSW was a failure to research how the machine should be operated and guarded. The machine was an example of a second-hand machine imported into NZ that probably did not comply in Holland (its country of origin) with the relevant European Union Council Directive EU 2009/104/EC (European Union, 2009).

Case studies E and F had ineffective SSW.

\section{Discussion}

The origin for this research was a request for advice on what constitutes a SSW under the NZ Health and Safety at Work Act 2015. The research has drawn on literature, the common law and criminal cases, and a set of small-scale case studies to explore what a SSW might include. The analysis showed that structuring, analysing and tabulating the case study data drew out the common content of a SSW. The tentative goal tree is a way of presenting the probable content of a SSW while avoiding presenting that content as a checklist.

The goal tree is used "bottom up" meaning that low order NCs must be achieved if higher level NCs are to be achieved. Similarly, the relevant NCs must be achieved if the CSF and then the goal are to be achieved. In this application, the lack of an effective document review made difficult the achievement of CSF and goal in four of the seven small scale case studies. This tentative goal tree confirms the need for effective links with other aspects of an organisation. Reference to the McKinsey 7-S model (Figure 1) places a SSW in the Systems and procedures variable and this links with, and similarly requires support from, the other six variables. The Makin \& Winder (2009, p. 330) "spider's web of interactions" (shown here as Figure 2) connects work practices with the seven other variables. However, neither the McKinsey 7-S model nor the Makin \& Winder web suggested all that a SSW might contain.

Together, these three approaches support the Munkman (1975) contention quoted earlier that a system of work requires coordination within the business so that "the work is carried out smoothly and competently" (pp.131-132), and not just for safety. Managers of an organisation need a clear understanding of the goals (at all levels) and the CSF and NC to achieve them. Development and use of the goal tree for a SSW show what needs to be achieved if a system of work is to be considered "safe".

Such a structured approach makes clearer if there is, in fact, a system of work and helps with assessment of whether the system is or will be "safe". This is an area that has not been researched, yet is of importance in (1) the management of an organisation and (2) knowing whether a given system of work would meet the expectations of regulatory agencies and the Courts. 
The research reported here, including the development of a goal tree, applies where work is "settled" (Munkman, 1975) and capable of being systematised, but may also apply to circumstances that are variable from day-to-day. If an activity is rarely carried out or a one-off, this may not be the case and a different solution (e.g., a permit to work) may be more relevant.

\section{Further research}

The philosophical foundations of the goal tree and its potential for use in occupational health and safety will be reported separately. No literature on use of the McKinsey 7-S model in occupational health and safety has been found. This and the validity of the tentative goal tree will be explored further and reported later.

Work is proceeding on cataloguing HSWA cases heard in the NZ District Court. Work to date has shown the reported cases form a body of data for further analysis. Some of the cases follow harm to the health of workers, providing an opportunity to explore the absence of 'health' from the duty for a safe system of work.

\section{References}

Addley, S., \& Quinn, D. (2019). Surgical smoke - what are the risks? The obstetrician \& gynaecologist, 21(2), 102-106. https://doi.org/10.1111/tog.12552

Borys, D., Cowley, S., Tepe, S., Morrell, A., \& MacDonald, W. (2012). Systems. Core Body of Knowledge for the Generalist OHS Professional. http://www.ohsbok.org.au/wpcontent/uploads/2013/12/11-Systems.pdf?ce18fc

Campbell, I. (1996). Compensation for Personal Injury in New Zealand: its rise and fall. Auckland University Press.

Chan, A., Wong, F., Chan, D., Yam, M., Kwok, A., Lam, E., \& Cheung, E. (2008). Work at height fatalities in the repair, maintenance, alteration, and addition works. Journal of Construction Engineering and Management, 134(7), 527-535.

Dawson, D., Chapman, J., \& Thomas, M. J. W. (2012, 2012/04/01/). Fatigue-proofing: A new approach to reducing fatigue-related risk using the principles of error management. Sleep Medicine Reviews, 16(2), 167-175. https://doi.org/10.1016/j.smrv.2011.05.004

Dekker, S. (2014). The Field Guide to Understanding 'Human Error' (3rd ed.). CRC Press.

Dettmer, H. W. (2007). The logical thinking process: a systems approach to complex problem solving. American Society for Quality.

Dettmer, H. W. (2011). Our goal is ... What is our goal? Goal Systems International. https://goalsys.com/books/documents/WhatisOurGoal-v5_000.pdf

Dyck, D. (2003). Occupational Health \& Safety: theory, strategy \& industry practice. LexisNexis. 
European Union. (2009). Directive 2009/104/EC of the European Paraliament and of the Council of 16 September 2009 concerning the minimum safety and health requirements for the use of work equipment by workers at (second individual Directive within the meaning of Article 16(1) of Directive 89/391/EEC). https://eur-lex.europa.eu/legal-content/en/TXT/?uri=CELEX:32009L0104

Healey, A. N., Primus, C. P., \& Koutantji, M. (2007). Quantifying distraction and interruption in urological surgery. Quality \& Safety in Health Care, 16(2), 135-139. http://dx.doi.org/10.1136/qshc.2006.019711

Holt, A. (2005). Principles of Health and Safety at Work (7th ed.). Routledge.

ISO. (2018). ISO 45001: 2018 Occupational health and safety management systems: Requirements with guidance for use. International Standards Organization, Geneva. https://www.iso.org/obp/ui/\#iso:std:iso:45001:ed-1:v1:en

IOSH. (2018, August). Golf course manager fatally claimed competence with chainsaw. IOSH Magazine. $\quad$ https://www.ioshmagazine.com/golf-course-manager-fatally-claimed-competencechainsaw

Jager, R., Cosman, M., Mackay, P., Mullins, M., Rose, P., \& Rosenberg, W. (2013). The Report of the Independent Taskforce on Workplace Health \& Safety. Independent Taskforce on Workplace Health and Safety. http://hstaskforce.govt.nz/documents/report-of-the-independent-taskforce-on-workplacehealth-safety.pdf

Lord Robens, A., Beeby, G., Pike, M., Robinson, S., Shaw, A., Windeyer, B., \& Wood, J. (1972). Safety and Health at Work: Report of the Committee, 1970-72 [Report Cmnd 5034]. HMSO. http://www.mineaccidents.com.au/uploads/robens-report-original.pdf

Makin, A.-M., \& Winder, C. (2009). Managing hazards in the workplace using organisational safety management systems: a safe place, safe person, safe systems approach. Journal of Risk Research, 12(3-4), 329-343. https://doi.org/10.1080/13669870802658998

Michie, S. (2002). Causes and management of stress at work. Occupational and Environmental Medicine, 59(1), 67-72.

Munkman, J. (1975). Employer's liability at common law (8th ed.). Butterworths.

OSH Branch. (2004). Safe Systems of Work. Occupational Safety and Health Council, Department of Labour. https://www.labour.gov.hk/eng/public/os/D/SafeSystem.pdf

Peace, C. (2008). A fresh approach to compensation. Safety \& Health Practitioner, 26(5), 50-54.

Peace, C. (2019). The effectiveness of risk assessments in informing decision makers [Unpublished $\mathrm{PhD}$ thesis], Victoria University of Wellington, New Zealand.

Peace, C., Lamm, F., Dearsly, G., \& Parkes, H. (2019). The evolution of the OHS profession in New Zealand. Safety Science, 120, 254-262. https://doi.org/10.1016/j.ssci.2019.07.005

Poole, C. J. M. (2008). Safe systems of work are needed for the diagnosis of occupational mental illness. Occupational Medicine, 58(1), 5-6. https://doi.org/10.1093/occmed/kqm137 
Praino, G., \& Sharit, J. (2016). Written work procedures: Identifying and understanding their risks and a proposed framework for modeling procedure risk. Safety Science, 82, 382-392. http://dx.doi.org/10.1016/j.ssci.2015.10.002

Robbins, S., Bergman, R., Stagg, I., \& Coulter, M. (2003). Management (3rd ed.). Pearson Education. Rochlin, G. I. (1999). Safe operation as a social construct. Ergonomics, 42(11), 1549-1560.

Stranks, J. (2010). Health and Safety at Work: An essential guide for managers (9th ed.). Kogan Page. Toft, B., \& Mascie-Taylor, H. (2005). Involuntary automaticity: a work-system induced risk to safe health care. Health Services Management Research, 18(4), 211-216. https://doi.org/10.1258/095148405774518615

Waring, A. (1996). Safety Management Systems. Chapman \& Hall.

Waterman, R., Peters, T., \& Phillips, J. (1980). Structure is not Organization. Business Horizons, 23(3), $14-25$.

Woodhouse, O., Bockett, H., \& Parsons, G. (1967). Compensation for Personal Injury New Zealand Government printer.

WorkSafe NZ. (2017). Performance Requirements: Health and Safety WorkSafe NZ. www.safeplus.nz

\section{Cases}

Blyth v Birmingham Waterworks, [1856], Alderson B.

Maritime New Zealand v Nino's Ltd, Antonio Innocenzo Basile, Shane Michael McCauley, NZDC 2536 [2020], Davidson J,. https://www.districtcourts.govt.nz/

Wilsons \& Clyde Coal Co Ltd v English, 1937 UKHL 2 AC 57 Wright LJ.

WorkSafe NZ v Enviro Waste Services Ltd, NZDC5425 [2016], Mill IG, J. http://www.districtcourts.govt.nz/

Worksafe NZ v Furntech Plastics Ltd, NZDC 18150 [2018], Sharp J,. https://www.districtcourts.govt.nz/

Worksafe NZ v Lets Bale Ltd, NZDC 4538 [2020], Crayton J,. https://www.districtcourts.govt.nz/

WorkSafe NZ v Precision Animal Supplements Limited, NZDC 19342 [2018], Roberts J,. https://www.districtcourts.govt.nz/

Worksafe NZ $v$ Toll Networks NZ Ltd, NZDC 11132 [2018], Paul J,. https://www.districtcourts.govt.nz/ 